\title{
The Effects of Rising Food and Fuel Costs on Poverty in Pakistan
}

\section{Theresa Thompson Chaudhry and Azam Amjad Chaudhry*}

\begin{abstract}
The dramatic increase in international food and fuel prices in recent times is a crucial issue for developing countries and the most vulnerable to these price shocks are the poorest segments of society. In countries like Pakistan, the discussion has focused on the impact of substantially higher food and fuel prices on poverty. This paper used PSLM and MICS household level data to analyze the impact of higher food and energy prices on the poverty head count and the poverty gap ratio in Pakistan. Simulated food and energy price shocks present some important results: First, the impact of food price increases on Pakistani poverty levels is substantially greater than the impact of energy price increases. Second, the impact of food price inflation on Pakistani poverty levels is significantly higher for rural populations as compared to urban populations. Finally, food price inflation can lead to significant increases in Pakistani poverty levels: For Pakistan as a whole, a $20 \%$ increase in food prices would lead to an $8 \%$ increase in the poverty head count.
\end{abstract}

\section{JEL Classification: D33, E3, R21}

Keywords: Pakistan, Poverty, Inflation, Household Budget, Food, Fue1

\section{Introduction}

Given the recent unprecedented levels of food and fuel prices, and their rapid rise, concern has arisen among policymakers, politicians, and international agencies about the effects of these on their populations and, in particular, the poor. According to the World Bank, global food prices have risen by $83 \%$ from February 2005 to February 2008 (see Figure 1). In the first quarter of 2008 alone, the price of wheat exported by the U.S.

\footnotetext{
* Associate Professor of Economics and Dean of Economics (respectively), Lahore School of Economics. The authors would like to gratefully acknowledge the research assistance of Mehak Ejaz and Usman Sikander.
} 
rose from $\$ 375$ to $\$ 440$ per ton (see Figure 2$)^{1}$. The executive director of the World Food Programme reported at a summit in London in April 2008 that rice prices had doubled over the previous five weeks. ${ }^{2}$ According to the U.S. Department of Agriculture, the price of rice has hit a 20 year record high. ${ }^{3}$ The World Bank predicts food prices to peak in 2009, but higher than average prices are expected to remain until 2015 for many food items. ${ }^{4}$

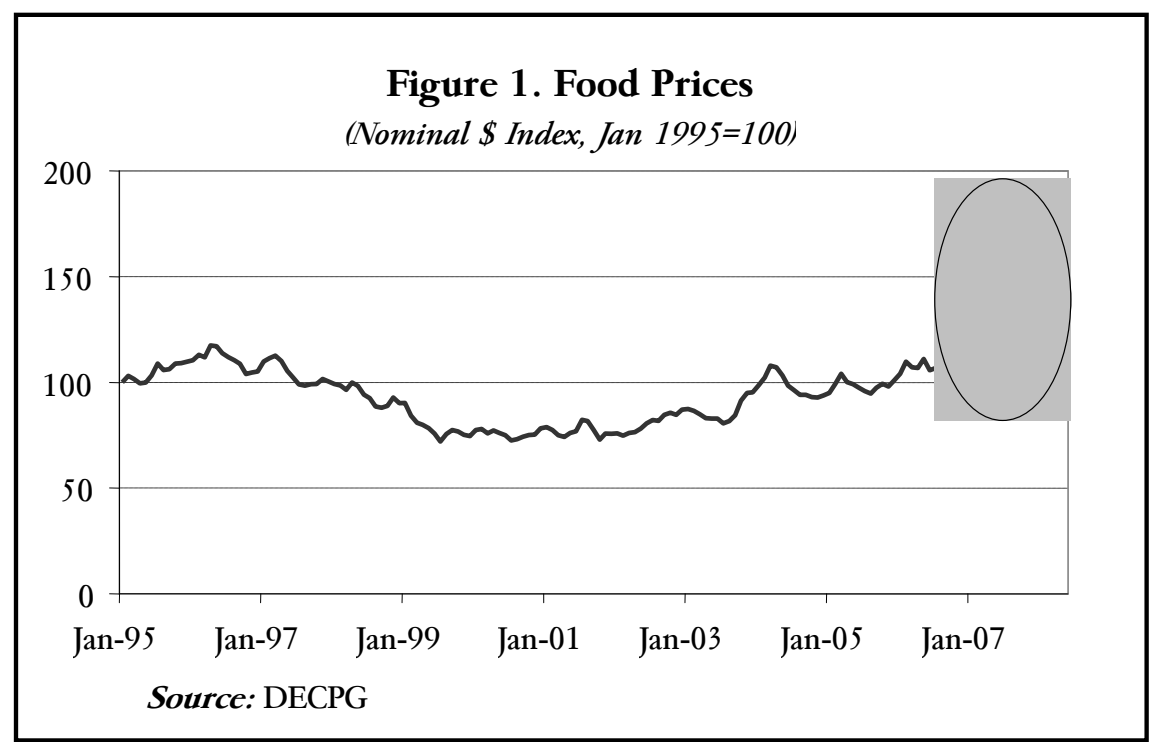

Source: World Bank (2008)

\footnotetext{
${ }^{1}$ World Bank, 2008.

2 Stringer, 2008.

${ }^{3}$ Walt, 2008.

${ }^{4}$ World Bank, 2008.
} 
Figure 2: Trends in Global Wheat Prices

Wheat prices (US \$) up nearly 200 percent

Nomian1 USD / metric ton

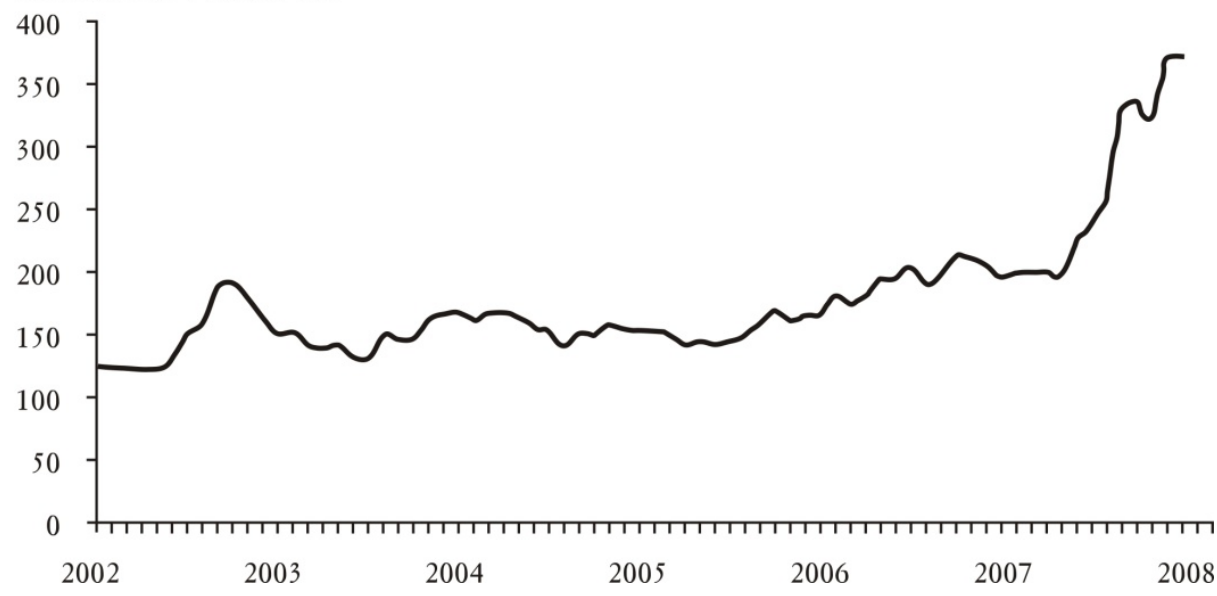

Source: World Bank (http://go.worldbank.org/DKQVYDJ7H0)

Government policies aimed at price stabilization (such as export and price controls and subsidies), international factors (such as a weak U.S. dollar) and domestic conditions (including weak infrastructure) may slow down or reduce the transmission of high world prices to local markets in developing countries. ${ }^{5}$ In fact, Pakistan moved to ban the export of wheat. ${ }^{6}$ Nonetheless, the effects of higher world food and fuel prices are being strongly felt in developing countries. Pakistan has seen a $20 \%$ increase in wheat prices between November 2007 and February 2008. ${ }^{7}$ The Federal Bureau of Statistics reported in November 2007 that food and beverage prices had risen $14.7 \%$ from October 2006 to October $2007 .{ }^{8}$ Indeed, the country's record-high inflation has been partially attributed to the sharp increases in food prices. As a result, half of Pakistan's population is considered to be "food insecure," according to the World Food Programme."

\footnotetext{
${ }^{5}$ World Bank, 2008.

${ }^{6}$ Birsel, 2008.

${ }^{7}$ Robinson, 2008.

${ }^{8}$ Sharif, 2008.

${ }^{9}$ According to the website of the Food Insecurity and Vulnerability Information and Mapping System (www.fivims.org), food insecurity is defined as, "a situation that exists when people lack secure access to sufficient amounts of safe and nutritious food for normal growth and development and an active and healthy life. It may be caused by the unavailability of food, insufficient purchasing power, inappropriate distribution, or inadequate use of food at the household level...Food insecurity may be chronic, seasonal or transitory."
} 
A recent World Bank working paper lists Pakistan as one of the twenty countries that the authors consider "at risk" due to the estimated impact of food prices on urban poverty (Dessus et al, 2008). The price of natural gas has risen dramatically, and the Pakistani government's fuel subsidies may be difficult to maintain given high fiscal deficits. ${ }^{10}$

The poorest segments of the population are particularly hard hit by the increases in food prices. According to World Bank president Robert Zoellick, food prices could deepen the poverty of up to 100 million people worldwide. $^{11}$ The World Food Programme reports that 20 million poor children are at risk. ${ }^{12}$ The U.N. fears that gains in poverty reduction are threatened by rising food prices. ${ }^{13}$ At the same time that prices have made food unaffordable to many, U.S. food aid has diminished. ${ }^{14}$ Long queues form at government stores in Pakistan ${ }^{15}$ and wheat ration cards have also been reinstituted. ${ }^{16}$ Violent protests have also erupted in the country. ${ }^{17}$

While high food prices hurt poor consumers, they are expected to help poor farmers; however, this depends critically on whether farmers can get access to needed fertilizer, irrigation, and markets. ${ }^{18}$

A number of factors, on both the supply and demand sides, have contributed to the rapidly ascending prices of staples. Among the demand side factors include the rising demand for food in China and India (and especially demand for meat, which requires large quantities of grain for animal feed). Demand for food is expected to double by 2030 according to the World Bank. ${ }^{19}$ Other sources of demand for food are the recent bio-fuel initiatives in developed countries including the U.S. and E.U., which eat into supplies of wheat, soy, maize, and palm oil. ${ }^{20}$ In the U.S. alone, two billion bushels of wheat were used in ethanol production. ${ }^{21}$ Expectations of shortages have led to speculation in commodities markets, further driving up prices. ${ }^{22}$

\footnotetext{
${ }^{10}$ Robinson, 2008.

${ }^{11}$ http://go.worldbank.org/5W9U9WTJB0

12 Stringer, 2008.

13 Stringer, 2008.

14 Dugger, 2008. From 2002 - 2006, the number of people fed by U.S. food aid fell from 105 million to 70 million.

${ }^{15}$ Robinson, 2008.

${ }^{16}$ Stringer, 2008.

${ }^{17}$ Walt, 2008.

${ }^{18}$ Stringer, 2008.

${ }^{19}$ Stringer, 2008.

${ }^{20}$ World Bank, 2008.

21 Sachs, 2007.

${ }^{22}$ Walt, 2008.
} 
Recent events have also affected the supply side of global food markets. Among these are high petroleum prices, which increase both the price of fertilizer and transport costs. ${ }^{23}$ Disruptive weather patterns have led to poor harvests in many regions: lack of rainfall in Australia and southern Africa, flooding in West Africa, cooler than normal temperatures in China, and abnormally warm weather in Europe. ${ }^{24}$ As a result of these factors, wheat production fell by 29 million metric tons between 2005-2006 and 2006$2007 .^{25,26}$

In addition to the international developments that have contributed to world price trends, a number of local factors in Pakistan can also be noted. Hoarding by speculating millers and retailers has been reported (both at the time of the elections and again more recently). ${ }^{27}$ Another factor that has been cited is the breakdown of the joint family system, putting nuclear families at greater risk when they face economic difficulties. ${ }^{28}$

The rest of the paper will proceed as follows. The data and basic statistics about the expenditure shares of food and fuel will be presented in Section II. The methodology and discussion of results will follow in Sections III and IV. Section V will present conclusions and policy implications.

\section{Data and Summary Statistics}

This paper uses household level data to analyze the impact of food and energy price increases on the poverty head count and the poverty gap ratio. The data is taken from two different sources: The Pakistan Social and Living Standards Measurement Survey (PLSM), 2004-2005 and the Punjab Multiple Indicators Cluster Survey (MICS), 2003-2004. Household level data was taken from these sources and missing data points and outliers were eliminated from the data sets. After the data was cleaned, the PSLM dataset contained 14,100 households (with 96,833 people), while the MICS dataset contained 29,342 households (with 192,398 people) The basic household level information taken from these surveys were (1) Household size, (2) Household

\footnotetext{
${ }^{23}$ Walt, 2008. As a caveat, the World Bank (2008) notes that energy costs have only contributed to about $15 \%$ of the rise in food costs.

${ }^{24}$ Walt, 2008.

${ }^{25}$ Sachs, 2007.

${ }^{26}$ Mitchell (2008) cites biofuels as the most important factor in food price inflation, with higher energy prices, a weak U.S. dollar, speculation, and export bans as other contributing factors. He considers increasing demand in developing countries and weather to be of lesser importance.

${ }^{27}$ IRIN, 2008 and Robinson, 2008.

${ }^{28}$ Comments of Kaisar Bengali, cited in IRIN, 2008.
} 
Income, (3) Disaggregated Household Expenditures, (4) Household location (Rural/Urban) and (5) Provincial location of the household (Punjab, Sindh, Northwest Frontier Province (NWFP) and Balochistan).

The first, and most important, piece of information taken from the surveys was the income (in rupees) per household member, which was then compared to the poverty line. The poverty line given by the Government of Pakistan in 2004-2005 (and used in the analysis of the PSLM data) was Rs. 878.64 per person and the poverty line given by the Government of Punjab in 2003-2004 (and used in the analysis of the MICS data) was Rs. 750 per person. Thus, a household was characterized as poor if the average income of its members was below the poverty line. Based upon this criteria, the poverty head count was calculated as the number of people as a proportion on the population that had incomes below the poverty line.

The second piece of information used in the analysis that follows was the disaggregated expenditures of each household. These expenditures can be broken down into a variety of categories, but for the analysis of the poverty head count, five major categories were taken: (1) Food Expenditures, (2) Energy Expenditures (which contained expenditures on gas, electricity, cooking and heating oil and other fuel related expenditures), (3) Educational Expenditures, (4) Medical Expenditures, and (5) Other Expenditures.

The interesting result of looking at this breakdown was the expenditure shares spent by individuals on these different categories, which is illustrated in Figures 3 and 4. As can be seen in Figure 3 (for Pakistan as a whole using PSLM data) and Figure 4 (for Punjab using MICS data), the majority of household expenditures in Pakistan were made up of food expenditures and these expenditures made up an average of about $60 \%$ of household expenditures at the lowest income levels for Pakistan and almost $70 \%$ of household expenditures at the lowest income levels for Punjab. Also, food expenditures fall as a proportion of total expenditures as the income level increases. After food, the second most major expenditure category across households was energy expenditures, which averaged about $10 \%$ of total household expenditures, and did not change across income levels. The third major category was medical expenditures, which averaged about $5 \%$ of total household expenditures, and did not vary across income groups. Finally, it can be seen that educational expenditures ranked the lowest in terms of percentage of household expenditures (averaging less than $5 \%$ of household expenditures) and increase as a proportion of income as income increases (though not substantially) in both Figure 3 (for Pakistan) and Figure 4 (for Punjab). 
Figure 3: Expenditure Shares on Major Budget Items by Income Per Capita Deciles in Pakistan (PSLM)

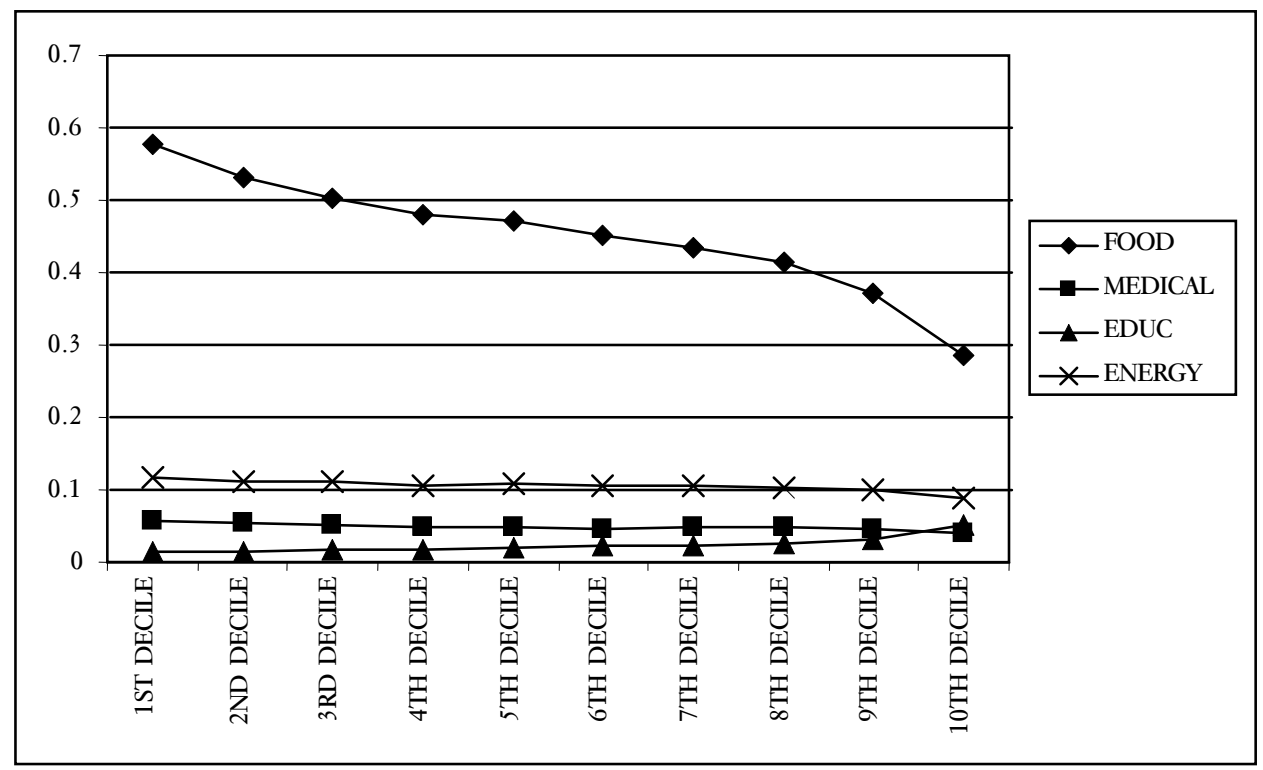

Figure 4: Expenditure Shares on Major Budget Items by Income Per Capita Deciles in Punjab (MICS)

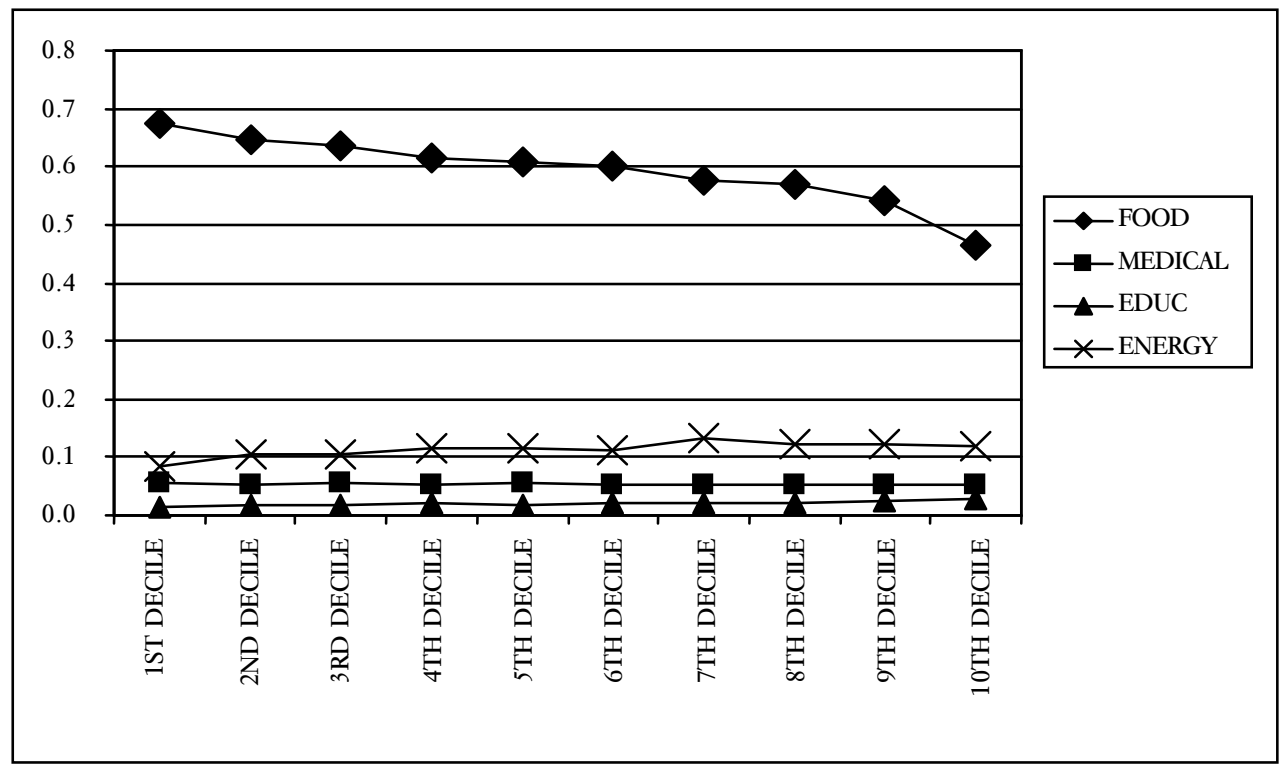




\section{Methodology}

In this paper, we measure the impact of food and energy price changes on two measures of poverty: the poverty head count and the poverty gap ratio.

In the analysis of the impact of price changes on poverty, this paper focuses on the impact of increases in food prices and increases in energy prices. This has been done for two reasons. First and foremost, much of the discussion on rising prices (and the impact of higher prices on the poor) has focused on food and energy prices. Second, the analysis has focused on these particular price changes since the households spend the greatest proportion of their income on food and energy and the impact of changes in these two will have the greatest impact on poverty.

At this stage it is important to note that the impact of food and energy price increases is looked at in a short-term framework. Thus, the effect of food price increases is analyzed without adjusting for the possibility of higher incomes in certain segments of the population due to higher food prices. Also, the analysis does not allow for the possibility of the consumer altering their consumption patterns due to price changes, which may not be an unrealistic assumption in the short run because of the inelasticity of demand for most goods purchased by consumers below or near the poverty line. This simplification makes the analysis far more manageable, though it can lead to the overestimation (or underestimation) of the impact of price increases on the poverty levels and for this reason the poverty impacts should be seen as short term impacts.

The analysis performed for this paper calculated the effects of price changes on poverty head counts and the poverty gap ratio for the PSLM and MICS datasets, and for sub-samples of both these datasets (for rural versus urban areas in both the PSLM and MICS datasets and for the different provinces in the PSLM dataset).

\section{The Poverty Head Count}

The poverty head count is simply the percentage of households whose income per capita falls below the poverty line. First, we will show (following Son and Kakwani, 2006b) how we plan to measure the impact of price changes on the poverty head count.

Given the basic expenditure minimization problem (as the dual of the utility maximization problem) from microeconomic theory, we can 
define the money metric indirect utility function of an individual, which measures the amount of money the consumer would need at price $p^{*}$ to achieve the same utility as he could under the prices $p$ and income $m$ :

$$
x\left(p ; p^{*}, m\right):=e\left(p, v\left(p^{*}, m\right)\right)
$$

If prices rise from $\mathrm{p}$ to $\mathrm{p}^{*}$, then the real income of the individual changes by:

$$
\Delta x=-\left[e\left(u, p^{*}\right)-e(u, p)\right]
$$

Using a Taylor expansion (and ignoring second order substitution effects), this expression becomes:

$$
\Delta x=-\sum_{i=1}^{m}\left(p_{i}^{n}-p_{i}\right) q_{i}(x)=\sum_{i=1}^{m} \Delta p_{i} q_{i}(x)
$$

where $q_{i}(x)=\frac{\partial e(u, p)}{\partial p_{i}}$ is the Hicksian demand for good $i$.

The elasticity of the money metric utility with respect to $p_{i}$, the price of $\operatorname{good} i$, is:

$$
\frac{\partial x}{\partial p_{i}} \frac{p_{i}}{x}=-\frac{p_{i} q_{i}(x)}{x}=-w_{i}(x)
$$

where $w_{i}(x)$ is the budget share of good $i^{29}$ According to Son and Kakwani (2006b), this elasticity can be interpreted as follows: for a $1 \%$ increase in the price of good $i$, the real income (as measured by the money metric utility, $x)$ will decline by $w_{i}(x) \%$. In other words, income would have to increase by $w_{i}(x)$ to maintain the same level of utility (or satisfaction) as before the price change (Son and Kakwani (2006a)). In the first part of our analysis, we use equation 4 to adjust down the per capita incomes given in the PSLM and MICS data set based on shocks to the prices of food and energy. Given that the price rises will reduce real incomes, the price shocks bring additional households below the poverty line. We then recalculate what the new poverty head count would be after each price shock. The price shocks analyzed are (1) A 1\% increase in the price of food, (2) A 5\%

${ }^{29}$ This result has been taken from Son and Kakwani, 2006b. 
increase in the price of food, (3) A $10 \%$ increase in the price of food, (4) A $20 \%$ increase in the price of food, (5) A 1\% increase in the price of energy, (6) A $5 \%$ increase in the price of energy, (7) A $10 \%$ increase in the price of energy, and (8) A $20 \%$ increase in the price of energy. Finally, we consider the impact of energy prices along with a rough estimation of the spillover effect of energy prices onto food prices: (9) A $1 \%$ increase in the price of energy plus spillover effects on food, (10) A $5 \%$ increase in the price of energy plus spillovers, (11) A $10 \%$ increase in the price of energy plus spillovers, and (12) A 20\% increase in the price of energy plus spillover effects on food. Our rough estimate of the spillover effects of energy prices onto food prices is based on the results of Baffes (2007), which estimated the elasticity of food prices with respect to oil prices to be $0.18 .^{30}$

\section{The Poverty Gap Ratio}

The second part of the analysis looks at the effects of price changes on another measure of poverty, the poverty gap ratio. The poverty gap is defined as:

$$
\theta_{\alpha}=\int_{0}^{z}\left(\frac{z-x}{z}\right)^{\alpha} f(x) d x
$$

where $\alpha=1, z$ is the poverty line, $x$ is the per capita income, and $f(x)$ is the density function (for the population). The poverty gap provides an indication of how much the poor households' per capita incomes fall short of the poverty line. In other words, it is considered a measure of the "depth" of poverty. The poverty gap ratio averages, over all poor households, the proportion by which each household's income $x$ is below the poverty line $z$.

Son and Kakwani (2006b) show that the elasticity of poverty with respect to the price of good $i$ is (again setting $\alpha=1$ for the poverty gap ratio):

$\eta_{\alpha i}=\frac{\partial \theta_{\alpha}}{\partial p_{i}} \frac{p_{i}}{\theta_{\alpha}}=\frac{\alpha}{\theta_{\alpha}}\left[\int_{0}^{z}\left(\frac{z-x}{z}\right)^{\alpha-1} w_{i}(x) f(x) d x-\int_{0}^{z}\left(\frac{z-x}{Z}\right)^{\alpha} w_{i}(x) f(x) d x\right]$

Using equation (5) above, we can estimate the elasticity of the poverty gap with respect to changes in the price of commodity $i$. Given that the commodities considered will be food and energy, we will be able to

${ }^{30}$ We calculate (roughly) the joint impact of energy and food prices, where for each $1 \%$ increase in energy prices, food prices also increase by $0.18 \%$. 
calculate the percentage change in the poverty gap ratio for a $1 \%$ change in the price of food or energy.

\section{Discussion of Results}

The poverty analysis performed for this paper can be viewed as a short term analysis. The reason that it is a short term analysis is because the impact of inflation on poverty follows many complex avenues and for this reason is difficult to fully quantify. A simple example is the impact of food inflation on poverty. An increase in food prices is usually not uniform, i.e. an increase in wheat prices by $10 \%$ are not automatically accompanied by a proportional increase in rice or other food items. So an increase in wheat prices (which is reflected in an increase in overall food prices) may not reduce the welfare of consumers as much as originally expected because consumers switch from wheat to rice or reduce their consumption of wheat. Similarly, an increase in wheat prices will lead to higher incomes for wheat producers, wheat processors, wheat distributors, etc, so an increase in wheat prices will lead to an increase in income for a certain segment of the population and the welfare impact of higher wheat prices on this segment of the population is more complex to analyze. Finally, the most obvious example is the impact of energy prices which lead not only to increases in the energy expenditures of consumers but also to eventual increases in the prices of all goods, which would have further negative consequences, though a certain segment of the population would also benefit.

But even after discussing these issues, a simple short-term analysis is important in its own right. First, substitution between commodities (or a reduction in commodity expenditures) within household budgets for households at or below the poverty line is usually difficult. Similarly, in the short term, increases in agricultural commodity prices will not be fully reflected in increases in the income of all related segments of society (or in other words, incomes are more 'sticky' than commodity prices). Finally, increases in energy prices take time to filter into the prices of all commodities. So, the analysis that follows can be viewed as the short-term impact of prices increases in poverty rates, whereas the long term impact will definitely be different.

The procedure followed in order to analyze the impact of inflation on poverty was as follows: For both the PLSM and MICS household datasets, the poverty head counts were calculated. Then using the budget shares of each household for food and energy, the impact of an increase in food prices and an increase in energy prices on the poverty head count and poverty gap ratio was calculated. Again, it should be noted that these price increases 
were looked at in a virtual vacuum: So as food prices increased, it was assumed that neither incomes nor other prices increased.

For the PSLM dataset, the impact of food and energy price increases on poverty was analyzed for the country as a whole, for the rural population, for the urban population, and for each of the four provinces, Punjab, Sindh, Northwest Frontier Province (NWFP) and Balochistan. For the MICS dataset, the impact of food and energy price increases on poverty was analyzed for Punjab as a whole, for the rural population and for the urban population.

\section{Effects of Price Increases on the Poverty Head Count}

The results for the aggregated PSLM dataset are presented in Table-1 and show the impact of increases in the price of food on the poverty head count. As shown, a $1 \%$ increase in food prices leads to a slight increase in the poverty head count (less than half of a percentage point), while a $5 \%$ increase in food prices leads to a slightly higher increase of 1.9 percentage points. The substantial changes in the poverty head count accompanied the $10 \%$ and $20 \%$ increases in the food prices, increasing the poverty head count by 3.8 and 7.7 percentage points respectively. The impact of higher energy prices on poverty is substantially smaller that the impact of food prices. A $1 \%$ increase in food prices has no significant effect on the poverty head count and $10 \%$ and $20 \%$ increases in energy prices push the head count up by 0.8 and 1.6 percentage points respectively. So, for Pakistan as a whole, the direct impact of energy price increases on poverty is smaller than the impact of food price increases. Using our rough calculations for the spillovers from energy price increases to food price increases, we see that $1 \%$ and $5 \%$ increases in energy costs raise the poverty headcount by less than one percentage point, and that the larger price increases of $10 \%$ and $20 \%$ raise the headcount by 1.6 and 3.1 percentage points respectively. As we can see, adding the secondary effects of energy prices on food prices is greater than the impact of energy prices alone, but is still significantly less than the impact of a comparable food price increase. Therefore, it is important to note that food price increases can lead to substantial increases in poverty. 
Table-1: Increase in Poverty Head Counts in Pakistan after Increases in the Prices of Food and Fuel (PSLM Data)

\begin{tabular}{|c|c|c|c|c|}
\hline & $\begin{array}{l}\text { 1\% Price } \\
\text { Increase }\end{array}$ & $\begin{array}{l}5 \% \text { Price } \\
\text { Increase }\end{array}$ & $\begin{array}{l}\text { 10\% Price } \\
\text { Increase }\end{array}$ & $\begin{array}{c}20 \% \text { Price } \\
\text { Increase }\end{array}$ \\
\hline Food Prices & $0.4 \%$ & $1.9 \%$ & $3.8 \%$ & $7.7 \%$ \\
\hline Energy Prices & $0.1 \%$ & $0.4 \%$ & $0.8 \%$ & $1.6 \%$ \\
\hline $\begin{array}{l}\text { Energy Prices }+ \\
\text { Spillover of Energy } \\
\text { on Food Prices }\end{array}$ & $0.2 \%$ & $0.7 \%$ & $1.6 \%$ & $3.1 \%$ \\
\hline
\end{tabular}

Source: Authors' Calculations

Table-2 shows the impact of food and energy price increases on the rural population of Pakistan. The rural poverty head count is higher than the national poverty head count. The interesting thing to note is the substantial impact that food price increases have on the rural poverty head count: A $10 \%$ increase in food prices pushes up the poverty head count by almost 5 percentage points while a $20 \%$ increase in food prices pushes the poverty head count up by 9.6 percentage points. So substantial increases in food prices can be seen to have a dramatic impact on rural poverty levels. However, recall that we have not taken into account the higher incomes that food producers could receive. Similar to the national case, energy price increases have substantially lower effects on rural poverty, and energy price increases plus spillovers to food prices have an intermediate effect.

Table-2: Increase in Poverty Head Counts in Rural Areas after Increases in the Prices of Food and Fuel (PSLM Data)

\begin{tabular}{lcccc}
\hline & $\begin{array}{c}\text { 1\% Price } \\
\text { Increase }\end{array}$ & $\begin{array}{c}\text { 5\% Price } \\
\text { Increase }\end{array}$ & $\begin{array}{c}\text { 10\% Price } \\
\text { Increase }\end{array}$ & $\begin{array}{c}\text { 20\% Price } \\
\text { Increase }\end{array}$ \\
\hline Food Prices & $0.6 \%$ & $2.5 \%$ & $4.9 \%$ & $9.6 \%$ \\
Energy Prices & $0.2 \%$ & $0.6 \%$ & $1.2 \%$ & $2.1 \%$ \\
$\begin{array}{l}\text { Energy Prices + } \\
\begin{array}{l}\text { Spillover of Energy } \\
\text { on Food Prices }\end{array}\end{array}$ & $0.4 \%$ & $1.1 \%$ & $2.0 \%$ & $3.7 \%$ \\
\hline
\end{tabular}

Source: Authors' Calculations 
The impact of higher food and energy prices on the urban population of Pakistan is shown in Table-3. As shown, price changes of $1 \%$ and $5 \%$ have a minimal impact. $10 \%$ and $20 \%$ increases in food prices push up the urban poverty head count by $2.4 \%$ and $5.1 \%$ respectively, while $10 \%$ and $20 \%$ increases in energy prices push the urban poverty head count up by $0.4 \%$ and $1.1 \%$. Energy price changes plus spillovers to food prices have an impact that is somewhere between that of a food price changes and an energy price change alone. The important point to come out of this discussion is that the impact of food price increases is substantially greater for the rural population as compared to the urban population, when we do not take into account the higher incomes that rural producers might earn.

Table-3: Increase in Poverty Head Counts in Urban Areas after Increases in the Prices of Food and Fuel (PSLM Data)

\begin{tabular}{|c|c|c|c|c|}
\hline & $\begin{array}{l}\text { 1\% Price } \\
\text { Increase }\end{array}$ & $\begin{array}{l}5 \% \text { Price } \\
\text { Increase }\end{array}$ & $\begin{array}{l}\text { 10\% Price } \\
\text { Increase }\end{array}$ & $\begin{array}{l}20 \% \text { Price } \\
\text { Increase }\end{array}$ \\
\hline Food Prices & $0.2 \%$ & $1.1 \%$ & $2.4 \%$ & $5.1 \%$ \\
\hline Energy Prices & $0.0 \%$ & $0.2 \%$ & $0.4 \%$ & $1.1 \%$ \\
\hline $\begin{array}{l}\text { Energy Prices + } \\
\text { Spillover of Energy } \\
\text { on Food Prices }\end{array}$ & $0.0 \%$ & $0.4 \%$ & $1.1 \%$ & $2.2 \%$ \\
\hline
\end{tabular}

Source: Authors' Calculations

The provincial level analyses are shown in Tables 4-7. The first thing worth noting is that the impact of energy price increases on poverty is, again, significantly smaller than the impact of food price increases, for all provinces. For all the provinces, the poverty head count increases by approximately $1-2 \%$ for a $20 \%$ increase in energy prices. The second interesting point worth noting is that although the impact of higher food prices is significant on all the provinces, the greatest impact of higher food prices is on the poverty head count of Balochistan (in which the poverty head count increases by 9.8 percentage points due to a $20 \%$ increase in food prices), followed by NWFP and Sindh. Overall, higher food prices lead to significantly higher poverty rates in all the provinces. 
Table-4: Increase in Poverty Head Counts in Punjab after Increases in the Prices of Food and Fuel (PSLM Data)

\begin{tabular}{|c|c|c|c|c|}
\hline & $\begin{array}{l}\text { 1\% Price } \\
\text { Increase }\end{array}$ & $\begin{array}{l}5 \% \text { Price } \\
\text { Increase }\end{array}$ & $\begin{array}{l}\text { 10\% Price } \\
\text { Increase }\end{array}$ & $\begin{array}{l}\text { 20\% Price } \\
\text { Increase }\end{array}$ \\
\hline Food Prices & $0.3 \%$ & $1.6 \%$ & $3.1 \%$ & $6.3 \%$ \\
\hline Energy Prices & $0.0 \%$ & $0.3 \%$ & $0.8 \%$ & $1.6 \%$ \\
\hline $\begin{array}{l}\text { Energy Prices }+ \\
\text { Spillover of Energy on } \\
\text { Food Prices }\end{array}$ & $0.1 \%$ & $0.7 \%$ & $1.4 \%$ & $2.8 \%$ \\
\hline
\end{tabular}

Source: Authors' Calculations

Table-5: Increase in Poverty Head Counts in Sindh after Increases in the Prices of Food and Fuel (PSLM Data)

\begin{tabular}{lcccc}
\hline & $\begin{array}{c}\text { 1\% Price } \\
\text { Increase }\end{array}$ & $\begin{array}{c}\text { 5\% Price } \\
\text { Increase }\end{array}$ & $\begin{array}{c}\text { 10\% Price } \\
\text { Increase }\end{array}$ & $\begin{array}{c}\text { 20\% Price } \\
\text { Increase }\end{array}$ \\
\hline Food Prices & $0.5 \%$ & $2.1 \%$ & $4.0 \%$ & $8.2 \%$ \\
Energy Prices & $0.2 \%$ & $0.5 \%$ & $0.7 \%$ & $1.5 \%$ \\
$\begin{array}{l}\text { Energy Prices + } \\
\begin{array}{l}\text { Spillover of Energy on } \\
\text { Food Prices }\end{array}\end{array}$ & $0.3 \%$ & $0.7 \%$ & $1.6 \%$ & $3.1 \%$ \\
\hline
\end{tabular}

Source: Authors' Calculations

Table-6: Increase in Poverty Head Counts in NWFP after Increases in the Prices of Food and Fuel (PSLM Data)

\begin{tabular}{|c|c|c|c|c|}
\hline & $\begin{array}{l}\text { 1\% Price } \\
\text { Increase }\end{array}$ & $\begin{array}{l}5 \% \text { Price } \\
\text { Increase }\end{array}$ & $\begin{array}{l}\text { 10\% Price } \\
\text { Increase }\end{array}$ & $\begin{array}{l}\text { 20\% Price } \\
\text { Increase }\end{array}$ \\
\hline Food Prices & $0.2 \%$ & $1.8 \%$ & $4.3 \%$ & $8.5 \%$ \\
\hline Energy Prices & $0.0 \%$ & $0.3 \%$ & $0.8 \%$ & $1.9 \%$ \\
\hline $\begin{array}{l}\text { Energy Prices }+ \\
\text { Spillover of Energy } \\
\text { on Food Prices }\end{array}$ & $0.1 \%$ & $0.5 \%$ & $1.7 \%$ & $3.5 \%$ \\
\hline
\end{tabular}

Source: Authors' Calculations 
Table-7: Increase in Poverty Head Counts in Balochistan after Increases in the Prices of Food and Fuel (PSLM Data)

\begin{tabular}{|c|c|c|c|c|}
\hline & $\begin{array}{l}1 \% \text { Price } \\
\text { Increase }\end{array}$ & $\begin{array}{l}5 \% \text { Price } \\
\text { Increase }\end{array}$ & $\begin{array}{c}\text { 10\% Price } \\
\text { Increase }\end{array}$ & $\begin{array}{c}\text { 20\% Price } \\
\text { Increase }\end{array}$ \\
\hline Food Prices & $0.6 \%$ & $2.8 \%$ & $4.8 \%$ & $9.8 \%$ \\
\hline Energy Prices & $0.2 \%$ & $0.5 \%$ & $1.1 \%$ & $1.8 \%$ \\
\hline $\begin{array}{l}\text { Energy Prices }+ \\
\text { Spillover of Energy } \\
\text { on Food Prices }\end{array}$ & $0.3 \%$ & $1.0 \%$ & $2.0 \%$ & $3.6 \%$ \\
\hline
\end{tabular}

Source: Authors' Calculations

The Punjab level results obtained from the MICS dataset show similar results. Table- 8 shows the results for Punjab as a whole and it can be seen that higher food prices lead to greater poverty in Punjab. 10\% and $20 \%$ increases in food prices lead to increases in the poverty head count of 4.7 and 9.8 percentage points respectively. The interesting point worth noting is that the MICS dataset shows a greater impact of food price increases on Punjab's poverty level than the PSLM dataset. As the results show, the MICS dataset implies that the Punjab poverty head count could be as adversely affected as the head counts in the other provinces as a result of higher food prices.

Table-8: Increase in Poverty Head Counts in Punjab after Increases in the Prices of Food and Fuel (MICS Data)

\begin{tabular}{lcccc}
\hline & $\begin{array}{c}\text { 1\% Price } \\
\text { Increase }\end{array}$ & $\begin{array}{c}\text { 5\% Price } \\
\text { Increase }\end{array}$ & $\begin{array}{c}\text { 10\% Price } \\
\text { Increase }\end{array}$ & $\begin{array}{c}\text { 20\% Price } \\
\text { Increase }\end{array}$ \\
\hline Food Prices & $1.7 \%$ & $2.8 \%$ & $4.7 \%$ & $9.0 \%$ \\
Energy Prices & $1.5 \%$ & $1.6 \%$ & $1.8 \%$ & $2.3 \%$ \\
$\begin{array}{l}\text { Energy Prices + } \\
\begin{array}{l}\text { Spillover of Energy } \\
\text { on Food Prices }\end{array}\end{array}$ & $1.6 \%$ & $1.9 \%$ & $2.3 \%$ & $3.8 \%$ \\
\hline
\end{tabular}

Source: Authors' Calculations

Table-9 and Table-10 show the impact of food and energy price increases on the rural and urban populations of Punjab. The first interesting point to note is that increases in food prices affect rural and urban poverty in Punjab similarly: For a $20 \%$ increase in food prices, the rural poverty 
head count increases by 9 percentage points, while the urban poverty head count increases by 9.3. Secondly, it is interesting to note from the MICS dataset results that the impact of energy price increases is slightly higher for the urban population in Punjab than for the rural population: A 20\% increase in energy prices will lead to an increase in the urban poverty head count of 2.8 percentage points, while it will lead to an increase in the rural poverty head count by 2.3 .

Table-9: Increase in Poverty Head Counts in Rural Punjab after Increases in the Prices of Food and Fuel (MICS Data)

\begin{tabular}{lcccc}
\hline & $\begin{array}{c}\text { 1\% Price } \\
\text { Increase }\end{array}$ & $\begin{array}{c}\text { 5\% Price } \\
\text { Increase }\end{array}$ & $\begin{array}{c}\mathbf{1 0 \%} \text { Price } \\
\text { Increase }\end{array}$ & $\begin{array}{c}\text { 20\% Price } \\
\text { Increase }\end{array}$ \\
\hline Food Prices & $1.5 \%$ & $2.8 \%$ & $4.8 \%$ & $9.3 \%$ \\
Energy Prices & $1.3 \%$ & $1.3 \%$ & $1.5 \%$ & $2.0 \%$ \\
$\begin{array}{l}\text { Energy Prices + } \\
\begin{array}{l}\text { Spillover of Energy } \\
\text { on Food Prices }\end{array}\end{array}$ & $1.4 \%$ & $1.7 \%$ & $2.2 \%$ & $3.5 \%$ \\
\hline
\end{tabular}

Source: Authors' Calculations

Table-10: Increase in Poverty Head Counts in Urban Punjab after Increases in the Prices of Food and Fuel (MICS Data)

\begin{tabular}{lcccc}
\hline & $\begin{array}{c}\text { 1\% Price } \\
\text { Increase }\end{array}$ & $\begin{array}{c}\text { 5\% Price } \\
\text { Increase }\end{array}$ & $\begin{array}{c}\text { 10\% Price } \\
\text { Increase }\end{array}$ & $\begin{array}{c}\text { 20\% Price } \\
\text { Increase }\end{array}$ \\
\hline Food Prices & $1.9 \%$ & $2.8 \%$ & $4.5 \%$ & $8.4 \%$ \\
Energy Prices & $1.9 \%$ & $1.9 \%$ & $2.2 \%$ & $2.8 \%$ \\
$\begin{array}{l}\text { Energy Prices + } \\
\begin{array}{l}\text { Spillover of Energy } \\
\text { on Food Prices }\end{array}\end{array}$ & $1.9 \%$ & $2.2 \%$ & $2.5 \%$ & $4.1 \%$ \\
\hline
\end{tabular}

Source: Authors' Calculations

The analysis presents some important results: First, the short term direct impact on poverty levels of food price increases is substantially greater than the short term direct impact of energy price increases and energy prices plus spillovers to food prices, and this result is consistent across provinces and across rural and urban populations. The primary reason for this is the fact that food is the largest item in poor households' budgets. Second, the short term impact of food price inflation on poverty 
is significantly higher for rural populations as compared to urban populations (though this result has be qualified by the fact the food price inflation will eventually impact rural incomes which in turn will reduce the impact of food price inflation on poverty). Third, the short term impact of food price inflation on poverty is significant across provinces and a $20 \%$ increase in food prices will lead to increases in the poverty head count ranging from $6 \%$ (for Punjab) to $10 \%$ (for Balochistan). Finally (and most importantly), across data sets, food price inflation can lead to significant increases in poverty. For Pakistan as a whole, a $20 \%$ increase in food prices would lead to an 8 percentage point increase in the poverty head count.

\section{Effects of Price Changes on the Poverty Gap Ratio}

Tables-11 and 12 present the results of calculating the elasticity of the poverty gap ratio with respect to price changes for the PSLM and the MICS data. Recall that the poverty gap is an indication of the depth of poverty, since it takes into account the degree to which the poor's incomes fall below the poverty line.

The figures for the elasticity of the poverty gap with respect to food prices does not vary much across provinces (for the PSLM data) nor the rural-urban divide (for both PSLM and MICS data). According to these calculations, increasing food prices by $1 \%$ would increase the poverty gap ratio by approximately $2 \%$. This is significantly higher than the poverty gap elasticity of 0.56 that Son and Kakwani (2006b) calculated for Brazil. There is slightly more variation in the elasticity figures with respect to energy prices. For the PSLM data, the elasticities vary from 0.33 to 0.53 , the highest being for NWFP and the lowest for Sindh. The elasticity of the poverty gap with respect to energy varies for Punjab between the PSLM and MICS data sets; in this case, the elasticity is greater when calculated from the PSLM data (0.44) rather than the MICS data (0.32). 
Table-11: Elasticity of the Poverty Gap Ratio With Respect to Changes in the Prices of Food and Energy (PSLM Data)

\begin{tabular}{lcc}
\hline & $\begin{array}{c}\text { Elasticity wrt Food } \\
\text { Prices }\end{array}$ & $\begin{array}{c}\text { Elasticity wrt Energy } \\
\text { Prices }\end{array}$ \\
\hline Overall & 2.1 & 0.44 \\
Rural & 2.11 & 0.42 \\
Urban & 2.06 & 0.51 \\
Punjab & 1.97 & 0.44 \\
Sindh & 2.06 & 0.33 \\
NWFP & 2.13 & 0.53 \\
Balochistan & 2.56 & 0.47 \\
\hline
\end{tabular}

Source: Authors' Calculations

Table-12: Elasticity of the Poverty-Gap Ratio With Respect to Changes in the Prices of Food and Energy (MICS Data)

\begin{tabular}{lcc}
\hline & $\begin{array}{c}\text { Elasticity wrt Food } \\
\text { Prices }\end{array}$ & $\begin{array}{c}\text { Elasticity wrt Energy } \\
\text { Prices }\end{array}$ \\
\hline Overall Punjab & 2.01 & 0.32 \\
Rural & 1.99 & 0.26 \\
Urban & 2.07 & 0.51 \\
\hline
\end{tabular}

Source: Authors' Calculations

\section{Conclusions and Policy Implications}

The results obtained from the simulated food and energy price shocks are both important for academics interested in the effect of inflation on poverty and for policymakers interested in designing measures aimed at reducing the impact of price shocks on the poor.

First, the results show that both food price shocks and energy price shocks cause higher levels of poverty, though the analysis implies a greater short run impact for food price shocks (assuming that food and energy price shocks are of equal magnitude). Thus policymakers designing measures to help the poor in terms of turbulent prices should focus first on controlling food price shocks and then on controlling energy price shocks, though it 
must be noted that large energy price shocks have a greater impact than small food price shocks.

Second, the results show that the negative impact of food price shocks falls disproportionately on the rural poor, as opposed to the urban poor. This means that policies designed at providing food security should start with the rural poor, though the urban poor is also substantially affected and should not be ignored. However, over the medium to longerterm, rural farmers will likely see welfare improvements as the selling price of their commodities rise.

Third, the negative impact of food price shocks is significant across provinces, which implies that both provincial and federal policies targeting poverty must address the issue of food security as soon as possible. As the results above show, a $20 \%$ increase in food prices could lead to a nearly 8 point higher poverty head count across provinces.

The policy level questions that arise from this discussion must focus on three major issues: First, the government must ensure household food security in the face of dramatic food price shocks through targeted safety nets. The safety nets can take the form of (a) aid and feeding programs, (b) employment programs (providing jobs and starting food for work programs), and (c) cash transfers to vulnerable groups such as the rural poor. Second, the government must ensure food security by controlling domestic food prices. The various mechanisms that have been discussed (and implemented with varying levels of success) are (a) targeted consumer subsidies/rations, (b) using buffer stocks to increase domestic food supply, and (c) reducing taxes on food items. Third, government policies must focus on the supply side in order to stimulate greater food production in the medium and long terms.

The issue facing Pakistan is not whether food and energy price shocks are going to occur, but rather the impact of the coming shocks and the actions which must be taken by the government in order to reduce the impact of these shocks on the poor. As the results in this paper show, the impact of the food and energy price shocks on the poor could be devastating and if the government fails to take immediate and targeted actions, the resulting increases in poverty could take a significant amount of time and effort to reverse. 


\section{References}

Baffes, John, 2007, “Oil Spills on Other Commodities,” World Bank Policy Research Working Paper \#4333, Washington DC: World Bank.

Birse1, Robert, 2008, "Export bans compounding Asia food insecurity WFP,” Reuters, April 22, 2008.

Dessus, Sebastien, Herrera, Santiago, and Rafael de Hoyos, 2008, "The Impact of Food Inflation on Urban Poverty," World Bank Policy Research Working Paper \#4666, Washington, DC: World Bank.

Dugger, Celia, 2008, “As Prices Soar, U.S. Food Aid Buys Less,” The New York Times, September 29, 2007.

IRIN, 2008, "Pakistan: Signs of increasing desperation as food prices rise further,” April 9, 2008, http://www.irinnews.org/Report.aspx? Reported $=77683$.

Mitchell, Donald, 2008, “A Note on Rising Food Prices,” World Bank Policy Research Working Paper \#4682, Washington, DC: World Bank.

Robinson, Simon, 2008, "Food Price Hikes Roil Pakistan,” Time Magazine, February 27, 2008.

Sachs, Jeffrey, 2007, "The Rising Cost of Nature," Project Syndicate, www.project-syndicate.org.

Sharif, Farhan, 2008, "Pakistan Inflation Accelerates to $9.3 \%$ on Food Prices,” Bloomberg.com, November 13, 2007.

Son, Hyun, and Nanak Kakwani, 2006a, "Measuring the Impact of Prices on Inequality: With Applications to Thailand and Korea," International Poverty Working Paper \#11, UNDP, January 2006.

Son, Hyun, and Nanak Kakwani, 2006b, Measuring the Impact of Price Changes on Poverty," International Poverty Working Paper \#33, UNDP, November 2006.

Stringer, David, 2008, "World Food Program warns of 'silent tsunami' of hunger," Associated Press, April 23, 2008. 
Walt, Vivienne, 2008, “The World's Growing Food-Price Crisis," Time Magazine, February 27, 2008.

World Bank, 2008, "Rising Food Prices: Policy Options and World Bank Response," Background note for the meeting of the Development Committee. 